\title{
Peran Pelatihan Kewirausahaan pada Motivasi dan Keterampilan Mahasiswa Jurusan Ekonomi Islam Fakultas Syariah dan Ekonomi Islam IAIN Pontianak
}

\author{
Anggatia Ariza* \\ Fakultas Syariah dan Ekonomi Islam, Institut Agama Islam Negeri Pontianak, Indonesia
}

\begin{abstract}
Unemployment is considered as one of the problems happened in developing countries. One of the efforts to overcome this problem is to accelerate the number of entrepreneurs. Furthermore, this research aims to perceive the roles of the entrepreneurs training on the entrepreneurship motivation and skill of Islamic Economics students at IAIN Pontianak. This research would be written by using action research. Besides, the data would be collected by interviewing, and observation. Then, the triangular method would be performed on the Chief of Islamic Economics Department to verify the real data. Moreover, the roles of entrepreneurship training on the entrepreneurship motivation are, mostly, students of Islamic Economics Department feel the growing of enthusiasm, the students' bravery to face the risks, and their self-esteem would be better. The roles of entrepreneurship training on the entrepreneurship skills are the creativity and innovation of students could be more developed. Then, it also could help the students to solve the problems in a better way on communication, leadership, strategy planning, and time balancing between study and business.
\end{abstract}

Keywords: Roles, motivation, creativity

\section{PENDAHULUAN}

Di Indonesia masih terdapat ketimpangan pendapatan dimana masih banyak orang yang tidak mempunyai penghasilan yang memadai akibat belum menemukan pekerjaan yang mampu memberikan penghasilan yang layak. Untuk mengatasi angka pengangguran, harus dilakukan upaya yang tepat dan cepat serta akurat. Salah satu upaya tersebut adalah dengan melakukan akselerasi pertumbuhan wirausahawan terutama di kalangan mahasiswa. Berdasarkan hasil wawancara dan kuesioner yang pernah dilakukan Kasmir, (2016) ke sekitar 500 mahasiswa sepanjang tahun 2005 di enam Perguruan Tinggi (PT) di Jakarta yang mewakili PT kelas bawah, kelas menengah dan kelas atas tentang keinginan mahasiswa setelah menyelesaikan pendidikan atau setelah memperoleh gelar sarjana, menunjukan hasil bahwa 76 persen menjawab akan melamar

\footnotetext{
*Email : anggatia_ariza@yahoo.co.id

Received: 06 Agustus 2018, Accepted: 06 Agustus 2018, Published: 18 Agustus 2018

p-ISSN : 2087 - 9954, e-ISSN : 2550 - 0066. DOI : http://dx.doi.org/10.26418/jebik.v7i2.26959
} 
kerja atau menjadi pegawai, 4 persen ingin berwirausaha, selebihnya ingin menjadi karyawan sambil berwirausaha. Hasil ini menunjukan bahwa orientasi para mahasiswa setelah lulus hanya untuk mencari kerja. Sementara itu lapangan kerja semakin sempit sehingga pengangguran terus bertambah (Kasmir, 2016).

Pentingnya penumbuhan jiwa kewirausahaan dimaksudkan untuk memberikan bekal kepada mahasiswa agar mahasiswa tersebut memiliki pola pikir, pola sikap dan pola tindak yang mengutamakan inovasi, kreativitas dan kemandirian. Jurusan Ekonomi Islam sebagai salah satu jurusan di IAIN Pontianak yang juga memiliki profil lulusan sebagai wirausahawan, merasa terpanggil untuk meningatkan akselerasi jiwa wirausaha khususnya bagi para mahasiswa yang kelak akan menjadi wirausahawan yang tangguh dan sukses di masyarakat. Guna menciptakan hal tersebut maka disusunlah kurikulum serta kegiatan seperti seminar maupun pelatihan yang mendukung keberhasilan jiwa kewirausahaan di tingkat perguruan tinggi. Berdasarkan penelitian oleh Wedayanti \& Giantari, (2016), semakin banyak penyediaan pengalaman dan penguasaan mengenai pelatihan kewirausahaan dengan melibatkan mereka dalam kegiatan belajar, pengembangan rencana bisnis, dan menjalankan usaha kecil yang diberikan kepada individu/mahasiswa, maka semakin tinggi niatnya untuk berwirausaha.

Oleh karena itu, penelitian ini bertujuan untuk mengetahui peran pelatihan kewirausahaan bagi mahasiswa jurusan Ekonomi Islam IAIN Pontianak. Maksud peran pelatihan dalam penelitian ini adalah peninjauan persepsi mahasiswa setelah mengikuti pelatihan. Dalam penelitian ini fokus pada motivasi dan keterampilan berwirausaha mahasiswa Jurusan Ekonomi Islam IAIN Pontianak. Penelitian ini diharapkan dapat memberikan informasi mengenai peran pelatihan kewirausahaan bagi mahasiswa sehingga dapat dijadikan rujukan serta pertimbangan untuk mengambil kebijakan tentang pelaksanaan kegiatan pelatihan kewirausahaan selanjutnya agar lebih efektif.

\section{KAJIAN LITERATUR}

\subsection{Wirausaha}

Kewirausahaan (enrepreneurship) adalah kemampuan kreatif dan inovatif yang dijadikan dasar, kiat dan sumber daya untuk mencari peluang menuju sukses (Suryana, 2011 : 2). Menurut Hamdani, (2012 : 11), kewirausahaan adalah suatu sikap, jiwa dan kemampuan untuk menciptakan sesuatu yang baru, bernilai dan berguna bagi dirinya dan orang lain. Sedangkan menurut Alma, (2016 : 21) seorang wirausaha adalah orang yang melihat adanya peluang kemudian menciptakan sebuah organisasi untuk memanfaatkan peluang tersebut. Dari beberapa pengertian wirausaha tersebut dapat disimpulkan bahwa wirausaha adalah seseorang yang mempunyai semangat untuk mandiri dalam memulai suatu usaha/bisnis, mampu menemukan peluang-peluang usaha dan berani menghadapi resiko. 
Menurut Geoffrey (1996) dalam Suryana, (2011 : 24), karakteristik dan watak kewirausahaan dapat dilihat pada tabel berikut:

Tabel 1. Karakteristik dan Watak Kewirausahaan

\begin{tabular}{ll}
\hline Karakteristik & Watak \\
\hline Percaya diri dan optimis & $\begin{array}{l}\text { Memiliki kepercayaan diri yang kuat, } \\
\text { ketidaktergantungan terhadap orang lain dan } \\
\text { individualis }\end{array}$ \\
\hline Berorientasi pada tugas dan hasil & $\begin{array}{l}\text { Kebutuhan untuk berprestasi, berorientasi laba, } \\
\text { mempunyai dorongan kuat, energik, tekun dan } \\
\text { tabah, tekad kerja keras serta inisiatif }\end{array}$ \\
\hline Berani mengambil resiko dan menyukai tantangan & Mampu mengambil resiko yang wajar \\
\hline Kepemimpinan & $\begin{array}{l}\text { Berjiwa kepemimpinan, mudah beradaptasi } \\
\text { dengan orang lain dan terbuka terhadap saran serta } \\
\text { kritik }\end{array}$ \\
\hline Keorisinalan & Inovatif, kreatif dan fleksibel \\
\hline
\end{tabular}

Sumber: Geoffrey (1996) dalam Suryana, (2011:24)

Menurut Hamdani, (2012 : 23), cara yang dapat dilakukan untuk menumbuhkan jiwa kewirausahaan adalah:

i. Melalui pendidikan formal, seperti program kegiatan dan mata kuliah.

ii. Melalui seminar-seminar kewirausahaan, dengan mengundang pakar dan praktisi kewirausahaan.

iii. Melalui pelatihan, dengan simulasi usaha baik yang dilakukan dalam ruangan (indoor) maupun di luar ruangan (outdoor).

iv. Otodidak, dengan berbagai berbagai media seperti biografi, media televisi, majalah, koran dan media lainnya dapat diakses sendiri untuk menumbuhkembangkan jiwa wirausaha

Menurut Suryana, (2011 : 67-68) ada beberapa faktor yang menentukan keberhasilan seorang wirausaha, seperti:

i. Kemampuan dan kemauan, jika kemampuan tidak diiringi dengan kemauan maupun kemauan yang tidak diiringi kemampuan maka akan menghalangi kesuksesan sebagai wirausaha.

ii. Tekad yang kuat dan kerja keras, jika memiliki tekad tetapi tidak disertai dengan usaha maupun berusaha tetapi tiak memiliki tekad yang kuat juga akan menghalangi kesuksesan sebagai wirausaha.

iii. Mengenal peluang yang ada dan berusaha meraihnya ketika ada kesempatan. 
Menurut Zimmerer (1996) dalam Suryana, (2011 : 68-69), penyebab kegagalan berwirausaha antara lain:

i. Tidak kompeten dalam manajerial atau mengelola usaha merupakan faktor utama yang menyebabkan ketidakberhasilan

ii. Kurang berpengalaman, baik dalam kemampuan teknik, visualisasi usaha, koordinasi, mengelola sumber daya manusia dan mengintegrasikan operasional.

iii. Kurang dapat mengendalikan keuangan, kekeliruan dalam keuangan akan menghambat operasional dan tidak lancar.

iv. Gagal dalam perencanaan, ketika perencanaan gagal maka akan mengalami kesulitan dalam pelaksanaan.

v. Lokasi yang kurang memadai, lokasi yang tidak strategis akan mengakibatkan ketidakefisienan.

vi. Kurangnya pengawasan peralatan, akan mengakibatkan tidak efisien dan tidak efektif.

vii. Sikap yang kurang sungguh-sungguh dalam berusaha, akan menyebabkan usaha yang dilakukan menjadi labil dan gagal.

\subsection{Motivasi}

Kebanyakan orang yang berhasil adalah orang yang memiliki motivasi tinggi. Menurut Alma, (2016 : 89), motivasi adalah kemauan untuk berbuat sesuatu. Motivasi berperan penting untuk mencapai tujuan tertentu agar meningkatkan produktivitas. Produktivitas berkaitan dengan kemampuan dalam menghasilkan barang atau berproduksi. Seorang wirausaha harus memperhatikan semua faktor yang bisa mempengaruhi produktivitas agar usaha dapat berjalan sukses dan mencapai kemajuan. Menurut Sutrisno dalam Hermuningsih \& Wardani, (2009 : 4), motivasi bisa dipengaruhi oleh beberapa faktor yang dapat dibedakan atas faktor internal dan faktor eksternal dari seseorang, antara lain :

i. Faktor internal, meliputi keinginan untuk dapat hidup, keinginan untuk dapat memiliki, keinginan untuk memperoleh penghargaan, keinginan untuk memperoleh pengakuan dan keinginan untuk berkuasa.

ii. Faktor eksternal, meliputi kondisi lingkungan kerja, supervisi yang baik, adanya jaminan pekerjaan, adanya penghargaan atas prestasi, peraturan yang fleksibel, status dan tanggung jawab.

\subsection{Keterampilan Berwirausaha}

Menurut Kamus Besar Bahasa Indonesia, keterampilan adalah kecakapan untuk menyelesaikan tugas. Keterampilan juga dapat diartikan sebagai kemampuan untuk menggunakan akal, fikiran, ide dan kreatifitas dalam mengerjakan, mengubah dan membuat sesuatu menjadi lebih bermakna sehingga menghasilkan sebuh nilai dari hasil pekerjaan tersebut. Berdasarkan pengertian tersebut, keterampilan berwirausaha adalah 
kemampuan menggunakan ide dan kreatifitas untuk menghasilkan sesuatu dengan nilai tambah untuk kepentingan pribadi ataupun kepentingan bersama.

Menurut Suryana, (2011 : 5), keterampilan yang harus dimiliki wirausaha antara lain:

i. Keterampilan konseptual dalam mengatur strategi dan memperhitungkan resiko

ii. Keterampilan kreatif dalam menciptakan nilai tambah

iii. Keterampilan dalam memimpin dan mengelola

iv. Keterampilan berkomunikasi dan berinteraksi

v. Keterampilan teknik usahan yang akan dilakukan

\subsection{Pelatihan Kewirausahaan}

Pelatihan merupakan suatu kegiatan yang ditujukan untuk memperbaiki kemampuan skill seseorang dalam kaitannya dengan aktivitas ekonomi. Pelatihan membantu memahami suatu pengetahuan praktis dan penerapannya, guna meningkatkan kemampuan keterampilan, kecakapan, dan sikap yang diperlukan oleh seseorang atau organisasi dalam usaha mencapai tujuannya.

Menurut Simamora, (1995 : 287), pelatihan merupakan serangkaian aktivitas yang dirancang untuk meningkatkan keahlian-keahlian, pengetahuan, pengalaman, ataupun perubahan sikap seorang individu. Pelatihan berkenaan dengan perolehan keahliankeahlian atau pengalaman tertentu. Program pelatihan berusaha mengajarkan bagaimana melaksanakan aktivitas atau pekerjaan tertentu.

Peran strategis dari kegiatan pelatihan khususnya pelatihan kewirausahan juga membuat pemerintah Republik Indonesia tergiat untuk ikut mendorong usaha ini. Pada UU RI No. 9 tahun 1995, Pemerintah, dunia usaha, dan masyarakat melakukan pembinaan atau pelatihan dan pengembangan dalam sumber daya manusia. Langkahlangkah yang ditempuh adalah:

i. Memasyarakatkan dan membudayakan kewirausahaan.

ii. Meningkatkan keterampilan teknis dan manajerial.

iii. Membentuk dan mengembangkan lembaga pendidikan, pelatihan, konsultasi usaha kecil.

iv. Menyediakan tenaga penyuluh dan konsultasi usaha kecil .

Program pelatihan kewirausahaan memberikan dampak positif terhadap pola pikir, kemampuan dan status kewirusahaan. Program pelatihan kewirausahaan juga berperan dalam membentuk intensi kewirausahaan berupa timbulnya keinginan peserta program untuk memulai dan mengembangkan bisnis serta melihat peluang usaha lain yang bisa dijalankan (Christanti, 2016). Pelatihan kewirausahaan dapat diikuti oleh semua kalangan, baik masyarakat umum atau mahasiswa. Pelatihan diperlukan bagi mahasiswa karena pelaku bisnis akan bertambah seiring dengan berkembangnya dunia bisnis (Resmi, 2013) . Beberapa program kewirausahaan yang ditawarkan kepada mahasiswa 
meliputi kemampuan menanggung resiko, pantang menyerah dan motivasi berwirausaha. Program ini diawali dengan pemberian workshop kemampuan berwirausaha kemudian dilanjutkan dengan magang di usaha-usaha yang menjadi binaan pihak Universitas sehingga diharapkan akan menghasilkan lulusan yang bermental wirausaha serta berminat membuka usaha.

Pelatihan kewirausahaan yang pernah diikuti oleh mahasiswa Jurusan Ekonomi Islam IAIN Pontianak ada yang diselenggarakan pihak luar dan diselenggarakan oleh jurusan. Pelatihan kewirausaahan yang diikuti mahasiswa Jurusan Ekonomi Islam yang diselenggarakan oleh pihak luar seperti Disperindag Provinsi Kalimantan Barat, Dispora Provinsi Kalimantan Barat, UNISMA, UKM S-KO, EXPO, BEKRAP (Badan Ekonomi Kreatif Pontianak) dan HIPMI. Pelatihan kewirausahaan yang diikuti mahasiswa Jurusan Ekonomi Islam yang diselenggarakan oleh Jurusan adalah kegiatan yang dilaksanakan bekerja sama dengan Lembaga Swa Bina Prakarsa.

\section{METODA PENELITIAN}

\subsection{Jenis Penelitian}

Dalam penelitian ini peneliti menggunakan pendekatan penelitian tindakan, yaitu penelitian tentang hal-hal yang terjadi di masyarakat atau kelompok sasaran dan hasilnya dapat dikenakan pada masyarakat yang bersangkutan (Arikunto, 2014 : 129).

\subsection{Pemilihan Lokasi dan Subjek Penelitian}

Lokasi penelitian ini adalah di Kampus Institut Agama Islam Negeri (IAIN) Pontianak. Peneliti memilih lokasi ini mengingat subjek yang akan diteliti adalah mahasiswa para mahasiswa Jurusan Ekonomi Islam IAIN Pontianak. Pertimbangan memilih mahasiswa Jurusan Ekonomi Islam karena salah satu profil lulusan Ekonomi Islam adalah wirausahawan sehingga mahasiswa Jurusan Ekonomi Islam memperoleh pengetahuan kewirausahaan dari pendidikan formal maupun non formal.

\subsection{Metode Pengumpulan Data}

Data dikumpulkan dari wawancara dan catatan lapangan. Catatan lapangan dipergunakan untuk mengetahui peningkatan motivasi dan pemunculan keterampilan mahasiswa. Sedangkan hasil observasi digunakan untuk mengetahui peningkatan kewirausahaan mahasiswa. Pada bagian refleksi dilakukan analisis data mengenai proses, masalah dan hambatan yang dijumpai, kemudian dilanjutkan dengan refleksi dampak pelaksanaan tindakan.

a. Perencanaan

Menyiapkan pedoman wawancara dan catatan lapangan.

b. Perlakuan / Tindakan 
Peningkatan efektivitas melalui pelatihan kewirausahaan yang terdiri teori dan praktek sesuai dengan rencana yang telah disusun.

c. Pengamatan / Observasi

Dilaksanakan saat kegiatan pelatihan meliputi observasi pelaksanaan kegiatan dan wawancara dengan mahasiswa yang berhubungan dengan motivasi dan keterampilan kewirausahaan.

d. Refleksi

Kegiatan pelatihan dianalisa dan sekaligus menyusun rencana perbaikan pada siklus berikutnya.

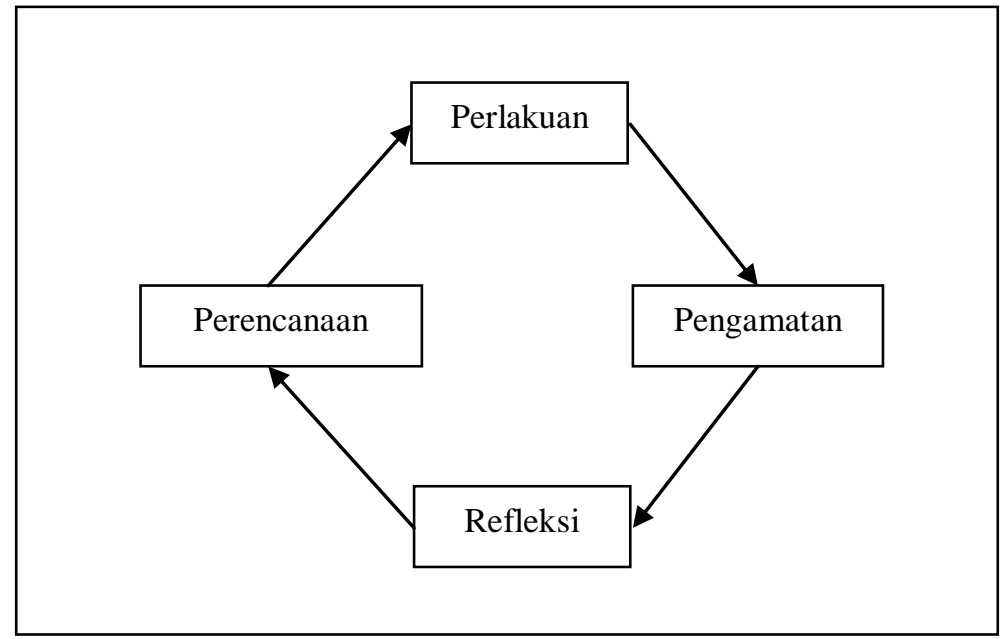

Sumber: Lewin (1990) dalam Arikunto, (2014 : 131)

\subsection{Analisis Data}

Prosedur, alat, sumber informasi dan cara analisis dapat dilihat pada tabel berikut:

Tabel 2. Prosedur, Alat, Sumber Informasi, Cara Analisis Penelitian

\begin{tabular}{|c|c|c|c|c|c|}
\hline No & Prosedur & Alat & & Sumber Informasi & Cara Analisis \\
\hline 1 & Menganalisis motivasi & $\begin{array}{l}\text { Pedoman } \\
\text { Recorder, } \\
\text { lapangan }\end{array}$ & $\begin{array}{r}\text { wawancara, } \\
\text { catatan }\end{array}$ & Mahasiswa & Analisis kualitatif \\
\hline 2 & $\begin{array}{l}\text { Menganalisis } \\
\text { keterampilan }\end{array}$ & $\begin{array}{l}\text { Pedoman } \\
\text { Recorder, } \\
\text { lapangan }\end{array}$ & $\begin{array}{r}\text { wawancara, } \\
\text { catatan }\end{array}$ & Mahasiswa & Analisis kualitatif \\
\hline
\end{tabular}

\subsection{Deskripsi Model Tindakan}

Model tindakan penelitian tindakan ini berupa pelatihan kewirausahaan yang dilaksanakan Jurusan Ekonomi Islam bekerja sama dengan Lembaga Swa Bina Prakarsa. 
Pelaksanaan tindakan meliputi kegiatan perencanaan, pelaksanaan, observasi dan refleksi.

a. Perencanaan

Pelatihan kewirausahaan diadakan bekerja sama dengan pemateri dari tim Lembaga Swa Bina Praksarsa yang dilaksanakan saat libur semester. Peerta merupakan mahasiswa Jurusan Ekonomi Islam.

b. Pelaksanaan Tindakan

Peserta merupakan mahasiswa Jurusan Ekonomi Islam angkatan 2014 yang dilaksanakan pada Juli - Agustus Tahun 2016 dan mahasiswa Jurusan Ekonomi Islam angkatan 2015 yang dilaksanakan pada Agustus - November Tahun 2017. Kegiatan terdiri dari teori dan praktik. Teori diberikan oleh tim di inkubator bisnis BI. Kegiatan praktik terdiri dari praktik produksi, pengemasan, dan pemasaran.

c. Observasi

Pemberian materi dengan sistem ceramah dan tanya jawab. Sebagian besar mahasiswa memahami tujuan dari kegiatan pelatihan kewirausahaan yaitu untuk membangun jiwa wirausaha. Materi-materi yang diberikan juga dianggap sudah sesuai dengan tujuan kegiatan tersebut. Materi yang diberikan merupakan materi tentang cara membangun usaha bagi yang belum punya usaha maupun yang sudah punya usaha. Mereka juga diberikan materi tentang cara membuat produk, menambah nilai produk, cara pengemasan bahkan cara memasarkan produk. Metode yang digunakan dirasakan menarik namun juga ada yang merasakan kurang menarik. Rajali, Achmad, Anita, Ayu, Wahyudi, Muriah, Robi, Resty, Yuhana dan Zuriansyah berpendapat bahwa metode yang digunakan menarik karena ada kombinasi antara ceramah, praktik dan diskusi. Sedangkan Fitriyani, Rika, Aramika dan Cicih merasa metode kurang menarik karena lebih banyak teori daripada praktiknya, ketika menyampaikan materi bahasa yang digunakan tidak dimengerti dan pemateri terpaku pada slide. Fathan Mun'im juga mengetahui metode yang digunakan dalam pelatihan merupakan campuran dari teori dan praktik.

Fathan Mun'im juga mengetahui metode yang digunakan dalam pelatihan merupakan campuran dari teori dan praktik. Praktik produksi membuat nugget pisang dan keripik pisang. Mahasiswa diajarkan cara memotong, menggoreng dan memberi aneka rasa. Setelah praktik produksi, mahasiswa diajarkan praktik pengemasan dan memberi label produk. Saat praktik pemasaran, mahasiswa diarahkan ke GOR untuk memasarakan produk, mahasiswa diberikan kebebasan untuk membawa produk masing-masing. Bagi mahasiswa angkatan 2015 setelah menyelesaikan kegiatan pelatihan kewirausahaan, mereka diberikan dana usaha 
kepada tiap-tiap kelompok dengan tujuan untuk membuka usaha sesuai kesepakatan kelompok masing-masing.

Motivasi dalam penelitian ini dilihat dari beberapa aspek yaitu tingkat antusiasme, keberanian menghadapi resiko, kepercayaan diri dan kesiapan untuk berwirausaha. Setelah mengikuti pelatihan kewirausahaan, sebagian besar mahasiswa Jurusan Ekonomi Islam merasakan peningkatan antusiasme. Mereka merasa lebih semangat dan wawasan tentang kewirausahaan semakin luas sehingga keinginan untuk membuka usaha menjadi lebih besar. Ada beberapa mahasiswa yang merasakan antusiasme sedikit menurun setelah mengikuti pelatihan, Fitriyani mengatakan pada saat mengikuti pelatihan antusiasme tinggi tetapi setelah itu menurun karena kesibukan sebagai mahasiswa. Pelatihan kewirausahaan juga mendorong mahasiswa untuk berwirausaha. Mereka memahami bahwa jika tidak percaya diri atau malu maka usaha tidak akan berjalan (Wahyudi). Resty menyadari bahwa sekecil apapun usaha yang dijalankan, saya adalah bos nya, jadi tidak perlu malu dan minder justru bangga karena punya penghasilan sendiri. Namun Cicih masih kurang percaya diri, menurutnya tidak masalah jika tidak bertatap muka (usaha lewat online), tapi masih malu-malu jika harus bertatap muka secara langsung. Beberapa usaha yang sudah dijalankan oleh mahasiswa seperti Syeckh, Akhmad, Anita, Ayu, Wahyudi, Muriah, Robi, Resty dan Yuhana. Syeckh menjual kue, Akhmad membuka usaha travel, Anita berjualan pulsa, Ayu jualan es tebu, Wahyudi jualan parfum, Robi mengelola usaha depot air dan gas, Resty berjualan baju, Muriah dan Yuhana menjual hasil kreativitas tangan seperti bunga dan keset.

Pada penelitian ini, keterampilan dilihat dari aspek kreativitas dan inovasi, penyelesaian masalah, komunikasi dan interaksi, kepemimpinan dan pengelolaan usaha, penyusunan strategi serta pembagian waktu. Akhmad menyatakan bahwa kreativitas dan inovasi sudah dilakukan karena usahanya bergerak di bidang jasa, Akhmad menyediakan cafe yang dilengkapi wifi sehingga konsumen bisa menunggu sambil bermain internet. Ayu juga melakukan kreasi pada saat menjual kripik bayam dengan memberikan variasi rasa. Wahyudi juga berkreasi pada usaha parfumnya dengan cara mencampur dua parfum sehingga menghasilkan aroma yang berbeda. Syech mengambil kue belum ada kemasan dari pihak pertama kemudian mengemas kue tersebut baru dijual, selama proses observasi dapat dilihat kue yang dikemas dengan plastik. Muriah dan Yuhana juga sudah menunjukan kreativitasnya melalui keset dan bunga yang bisa dibuat sesuai dengan pesanan konsumen, produk dapat disesuaikan dengan bahan, bentuk dan warna. Pada saat observasi, Muriah dan Yuhana sedang membuat keset yang dibuat dari bola-bola dari bahan benang wol, mereka juga membuat buket bunga dari pita kain kemudian dihias dengan manik-manik. 
Walaupun banyak yang merasakan ada perkembangan kreativitas, masih ada mahasiswa yang merasakan tidak ada perubahan. Seperti Robi yang merasakan tidak ada kreativitas karena usaha yang dijalankannya adalah depot air, Robi merasakan hanya berkreasi pada sistem pemasarannya saja. Hal ini hampir sama dengan Rajali, karena setelah pelatihan bekerja dibidang percetakan jadi dirasakan tidak mendukung adanya kreativitas, karena yang dikerjakan adalah sesuai dengan permintaan konsumen.

Saat observasi diketahui bahwa dalam rangkaian pelatihan kewirausahaan yang dilaksanakan oleh Jurusan Ekonomi Islam bekerja sama dengan Lembaga Swa Bina Prakarsa terdapat praktik yang memancing mahasiswa untuk kreatif. Ketika praktik mahasiswa diajarkan membuat keripik pisang dan mengemasnya sehingga siap untuk dijual, kemudian mahasiswa diberikan kesempatan untuk membuat produk sendiri yang akan dijual saat praktik pemasaran di GOR pada hari minggu. Dalam kesempatan ini peneliti menemukan banyak variasi produk yang ditawarkan mahasiswa, seperti puding, keripik, pisang keju, minuman, dan lain-lain. Pelatihan ini disertai dengan pemberian dana kepada mahasiswa angkatan 2015 untuk melaksanakan usaha. Dana ini diberikan kepada tiap kelompok, dimana masingmasing kelompok diberikan kebebasan dalam memilih produk. Dari sini juga terlihat kreativitas masing-masing kelompok. Ada yang menjual kripik upi jalar, ayam geprek hijrah, thai tea, pentol kuah, dan lain-lain.

Mahasiswa memahami dalam berusaha akan menghadapi masalah baik masalah yang berat ataupun ringan. Aramika dan Resty menyadari bahwa usaha yang mereka lakukan kurang berhasil karena pencatatan keuangan yang tidak baik, dengan adanya pelatihan mereka mengetahui sistem pencatatan yang baik sehingga bisa memperbaiki kegagalan yang dialami. Sedangkan Syeckh merasakan kalau masalah yang dihadapinya tidak terlalu berat karena hanya bergerak di sektor usaha kecil.

Kemampuan mahasiswa dalam memimpin dan mengelola usaha juga berkembang dengan mengikuti pelatihan. Resty membuka usaha jualan baju bersama temannya, mengetahui temannya kurang mampu dalam pembukuan, Resty mengambil alih tugas tersebut dan mengarahkan temannya ke tugas yang lain. Robi dan Wahyudi bahkan sudah memperkerjakan orang lain untuk menjaga toko mereka. Rika yang baru berjualan kue berbagi tugas dengan ibunya, Rika membuat kulit dan isi kue diserahkan ke ibunya. Hal ini menunjukan bahwa mereka sudah mempunyai kemampuan mengelola usaha.

Penyusunan strategi juga sudah dilaksanakan oleh mahasiswa seperti Syech yang awalnya menjual roti dengan harga $\mathrm{Rp} 1500$ jika sudah sore akan menurunkan harga menjadi Rp 1000 agar roti yang dibawanya habis. Rika membawa kue yang dibuatnya ke pasar, ada yang sudah digoreng agar bisa langsung dimakan dan ada yang belum digoreng agar bisa digoreng sendiri oleh pembeli sehingga lebih fresh. 
Strategi pemasaran juga lebih baik seperti Resty dan Yuhana yang memasarkan produknya lewat media sosial seperti instagram, whats app dan facebook.

Mahasiswa juga mulai berusaha memanajemen waktu, Syech mengatakan jika ada jam kuliah maka Syech akan minta tolong saudaranya untuk menjaga usaha kuenya. Fitriyani menjalankan usaha jualan kuenya ketika sedang liburan kuliah agar tidak menggangu kuliah. Yuhana mengerjakan pesanan ketika waktu luang, hal ini terlihat ketika ada pesanan buket bunga pada tanggal 4 November 2017 bisa jadi sesuai pesanan warna pada tanggal 14 November 2017, pesanan ini dikerjakan diluar waktu kuliah sehingga pesanan selesai selama sepuluh hari. Sedangkan Wahyudi dan Robi tidak mengalami masalah pembagian waktu karena sudah ada karyawan. Anita usaha jual pulsa dan Resty jual baju lewat online sehingga tidak mengalami masalah dengan waktu. Zuriansyah masih belum bisa membagi waktu antara belajar dan berusaha.

\section{d. Refleksi}

Berdasarkan hasil wawancara dan observasi, sebagian besar mahasiswa mengalami peningkatan motivasi berwirausaha. Ada beberapa mahasiswa mewujudkan motivasi dengan berwirausaha, namun ada juga yang tidak karena keterbatasan waktu dan modal. Bagi mahasiswa angkatan 2015 yang diberikan dana usaha, keterbatasan modal bagi mahasiswa yang ingin berwirausaha dapat berkurang. Pemberian dana pada kelompok menyebabkan terdapat beberapa produk dalam suatu kelompok sehingga menambah variasi usaha mahasiswa. Namun ada juga beberapa kelompok yang tidak semua anggota nya aktif menjalankan usaha karena kesibukan masing-masing. Lembaga Swa Bina Prakarsa juga memberikan penawaran berupa pendirian usaha yang terdaftar seperti dalam bentuk $\mathrm{CV}$, tujuannya adalah agar para peserta setelah mengikuti kegiatan dapat memiliki usaha sendiri. Pembayaran ini bukan merupakan suatu keharusan, sehingga bagi peserta yang belum bisa atau belum tertarik boleh untuk tidak mengikuti praktik maupun pendirian usaha.

\section{HASIL PENELITIAN DAN PEMBAHASAN}

\subsection{Peran Pelatihan Kewirausahaan pada Motivasi Berwirausaha Mahasiswa Jurusan Ekonomi Islam IAIN Pontianak}

Suratna, (2010) menyatakan bahwa salah satu cara yang cukup efektif dalam menumbuhkan jiwa kewirausahaan pada mahasiswa melalui pembelajaran adalah dengan mengajarkan kasus-kasus. Menurut Criman dalam Suratna, (2010), kasus-kasus entrepreneurial antara lain penciptaan bisnis baru, manajemen usaha kecil, isu bisnis keluarga dan sebagainya. Kasus tersebut juga harus sesuai untuk dibahas di kelas, seperti case fokus, yaitu bahwa keputusan kunci di dalam kasus sudah dirancang terlebih dahulu. Kasus tersebut dapat terpusat secara luas yang berarti konsentrasi pada 
keputusan penciptaan suatu bisnis baru tersebut layak atau tidak, kapan, dimana atau bagaimana suatu produk baru di bawa masuk ke pasar. Secara sempit, dapat berisi di mana lokasi bisnis baru tersebut yang paling baik, kesempatan untuk menambah jenis baru yang segaris dengan produk yang sudah ada dan sebagainya.

Dunia wirausaha penuh dengan resiko dan tantangan seperti persaingan, harga turun maupun barang tidak laku, namun hal ini bisa dihadapi dengan perhitungan serta pertimbangan yang baik (Alma, 2016 : 54). Setelah mengikuti pelatihan, keberanian mahasiswa menghadapi resiko juga menjadi lebih baik. Mereka memahami bahwa setiap usaha akan selalu ada resiko, kegagalan dan kerugian merupakan suatu hal yang wajar. Namun dalam menghadapi resiko tergantung pada pilihan yang diambil. Hal ini sesuai dengan Meredith (1996) dalam (Suryana, 2011 : 41) bahwa ketika menghadapi situasi resiko dan ketidakpastian ada dua alternatif atau lebih yang harus dipilih yaitu alternatif yang mengandung resiko dan alternatif yang konservatif. Pilihan terhadap resiko bergantung pada daya tarik setiap alternatif, siap untuk mengalami kerugian dan kemungkinan relatif untuk sukses atau gagal.

Menurut Suryana, (2011), percaya diri (yakin, optimis dan penuh komitmen) dalam menentukan dan menjalankan sesuatu serta percaya diri dapat mengatasi berbagai resiko merupakan faktor mendasar yang harus dimiliki wirausaha. Seseorang yang memiliki jiwa wirausaha akan merasa yakin bahwa tindakan yang diambil akan berhasil walaupun akan menghadapi rintangan Kepercayaan diri mahasiswa menjadi lebih baik setelah mengikuti pelatihan. Keberanian dalam mengambil resiko yang diikuti dengan optimisme dan kepercayaan diri akan mendorong seseorang untuk berinisiatif dan siap untuk memulai usaha. Berinisiatif adalah keinginan untuk selalu mencari dan memulai sesuatu dengan tekad yang kuat (Suryana, 2011 : 40). Pelatihan kewirausahaan bisa mempengaruhi perilaku inisiatif dan kesiapan mahasiswa untuk berwirausaha. Dalam memasuki dunia bisnis, terdapat beberapa proses yang harus dijalani, yaitu ide, modal, barang dan jasa, pasar, serta profit. Pengembangan ide dalam melihat peluang usaha dapat bersumber dari pengalaman pribadi, minat, penemuan tidak sengaja dan pencarian ide dengan dasar pertimbangan. Modal dalam usaha bukan hanya modal berupa uang, tapi juga berupa barang, orang (tenaga kerja atau skill) dan fasilitas. Menentukan barang dan jasa yang akan dijadikan objek bisnis harus memiliki pasar (dibutuhkan konsumen dan laku di pasaran). Mengamati peluang pasar sebelum menciptakan barang dan jasa. Proses yang terakhir adalah keuntungan dari penjualan barang dan jasa yang ditawarkan. (Hamdani, 2012).

\subsection{Peran Pelatihan Kewirausahaan pada Keterampilan Berwirausaha Mahasiswa Jurusan Ekonomi Islam IAIN Pontianak}

Pada penelitian ini, keterampilan dilihat dari aspek kreativitas dan inovasi, penyelesaian masalah, komunikasi dan interaksi, kepemimpinan dan pengelolaan usaha,

penyusunan strategi serta pembagian waktu. Kreativitas merupakan kemampuan 
seseorang untuk melahirkan sesuatu yang baru, baik berupa gagasan maupun karya nyata, yang relatif berbeda dengan apa yang telah ada sebelumnya Dedi dalam (Alma, 2016 : 70). Terdapat kegiatan-kegiatan yang dapat meningkatkan kreativitas seperti pemberian izin, toleransi pada kegagalan, ungkapkan rasa penasaran, memandang masalah sebagai satu tantangan, pengadaan pelatihan, pemberian fasilitas, toleransi terhadap waktu, pemberian penghargaan dan memperlihatkan contoh (Alma, 2016:75).

Melalui pelatihan kewirausahaan membantu mahasiswa dalam menyelesaikan masalah dengan baik. Mereka menyadari bahwa dalam usaha pasti ada masalah sehingga harus tenang agar bisa mencari solusinya. Pelatihan kewirausahaan juga mempengaruhi kemampuan komunikasi dan interaksi mahasiswa. Dalam berwirausaha, komunikasi mempunyai peranan penting karena untuk memasarkan produk serta menjalin jaringan yang lebih luas. Komunikasi yang terjadi dengan sesama peserta di pelatihan juga memberikan dampak terhadap perluasan jaringan usaha. Karena banyak pengusahapengusaha yang mengikuti pelatihan kewirausahaan, mahasiswa bisa mencari informasi dan bertukar pikiran tentang dunia usaha, bahkan mereka mempunyai jaringan jika ingin memasarkan produk. Menurut Alma, (2016), dengan pandai berkomunikasi yaitu menuangkan buah pikiran dalam bentuk ucapak yang jelas, menggunakan tutur kata yang baik, mampu menarik perhatian orang lain maka akan membantu seseorang mengembangkan karir masa depannya.

Hal ini sesuai dengan yang disampaikan oleh Fathan Mun'im, yaitu mahasiswa sudah tidak malu menawarkan produk ke dosen-dosen, di bawa ke kelas-kelas, mereka sudah menghilangkan jiwa gengsinya, karena mereka punya tanggung jawab yang harus mereka laksanakan dan dengan itu mereka terdorong untuk berwirausaha. Yang biasanya malu-malu buat ngomong sekarang sudah berani menawarkan produk-produknya. Ketika observasi saat praktik pemasaran di GOR, peneliti menemukan bahwa komunikasi dan interaksi sangat mempengaruhi penjualan, walau mereka membawa produk dan dilihat oleh calon pembeli tapi karena tidak ada komunikasi dan interaksi maka calon pembeli tidak tertarik untuk membeli, hal ini sesuai dengan yang disampaikan oleh mahasiswa saat evaluasi, bahwa mereka mengalami kesulitan menawarkan produk ke calon pembeli sehingga produk yang dibawa masih tersisa. Bagi mahasiswa yang berani berkomunikasi dengan calon pembeli, berdampak pada barang dagangan yang laku dibeli.

Kemampuan mahasiswa dalam memimpin dan mengelola usaha juga berkembang dengan mengikuti pelatihan. Menurut Alma, (2016 : 163), terdapat tiga variabel utama yang tercakup dalam kepemimpinan yaitu kepemimpinan melibatkan orang lain, kepemimpinan menyangkut distribusi kekuasaan dan kepemimpinan menyangkut penamaan pengaruh dalam rangka mengarahkan bawahan. Walaupun masih usaha yang sederhana, mereka mampu memimpin orang-orang yang terlibat dalam usaha yang mereka jalani. Pelatihan kewirausahaan juga membantu mereka dalam menyusun strategi. Menurut Suryana, (2011 : 159-160), terdapat beberapa keputusan strategis yang diperlukan seperti perubahan produk barang dan jasa, strategi yang menyangkut 
penetrasi pasar, ekspansi pasar, diversifikasi produk dan jasa, integrasi regional atau ekspansi usaha, kemampuan untuk memperoleh modal investasi, analisis sumber daya manusia, analisis pesaing, kemampuan untuk menopang dan memodifikasi strategi, penentuan harga barang atau jasa, interaksi dengan masyarakat luas. Beberapa strategi yang dilakukan mahasiswa adalah penurunan harga, pengemasan dan pemasaran online.

Pelatihan kewirausahaan memberikan materi tentang manajemen waktu yang membantu mahasiswa mengatur waktu antara kuliah dan menjalankan usaha. Menjalankan usaha ketika masih kuliah memerlukan komitmen dan kedisiplinan dalam mengatur waktu. Menurut Alma, (2016 : 65), agar dapat memanfaatkan waktu sebaikbaiknya maka ada beberapa hal yang dapat diperhatikan seperti buat rincian pekerjaan yang akan dilakukan setiap hari dan coret yang sudah dikerjakan; hubungi via telepon sebelum mengunjungi/bertemu dengan seseorang; siapkan pulpen dan kertas catatan kecil; jaga waktu sholat; memanfaatkan waktu lowong; merencanakan waktu dalam perjalanan; menghindari orang-orang yang tidak produktif; tidak perlu bertemu langsung jika hal yang ingin dibicarakan bisa dilakukan lewat teknologi komunikasi.

\section{SIMPULAN}

Untuk mengatasi jumlah pengangguran dan menambah lapangan pekerjaan, diperlukan dorongan untuk menumbuhkan jiwa kewirausahaan. Salah satu upaya untuk mendorong jiwa kewirausahaan adalah dengan pelaksanaan pelatihan kewirausahaan yang diharapkan dapat menumbuhkan motivasi dan keterampilan berwirausaha. Sebagian besar mahasiswa Jurusan Ekonomi Islam setelah mengikuti pelatihan kewirausahaan merasakan peningkatan antusiasme, namun ada juga yang mengalami penurunan antusiasme karena sistem praktik dan kesibukan. Mahasiswa mulai berani menghadapi resiko berusaha karena memahami setiap usaha ada resiko, tetapi ada juga yang lebih memilih untuk menghindari resiko. Kepercayaan diri juga menjadi lebih baik, namun ada juga yang masih ada yang malu-malu. Sebagian besar mahasiswa juga siap untuk berwirausaha. Untuk memacu motivasi berwirausaha diperlukan suatu usaha yang berkelanjutan sehingga usaha yang diinginkan bisa terwujud.

Setelah mengikuti pelatihan kewirausahaan, kreativitas dan inovasi mahasiswa semakin berkembang yang dapat dilihat dari kemampuan untuk mengolah usaha yang digeluti. Pelatihan juga membantu mahasiswa dalam menyelesaikan masalah dengan baik, mahasiswa merasakan lebih baik dalam berkomunikasi, Kemampuan mahasiswa dalam memimpin dan mengelola usaha juga berkembang yang terlihat dari kemampuan mereka mengarahkan orang-orang yang terlibat dalam usaha mereka. Kemampuan menyusun strategi juga berkembang, menyesuaikan kondisi yang dihadapi. Dengan berjalannya waktu, kemampuan untuk mengatur waktu antara kuliah dan menjalankan usaha juga semakin baik, mereka bisa membuat produk dalam waktu luang, maupun meminta bantuan orang-orang yang diajak berkerja sama. 
Penelitian ini masih terbatas pada mahasiswa Jurusan Ekonomi Islam Fakultas Syariah dan Ekonomi Islam IAIN Pontianak, diharapkan ada penelitian selanjutnya yang membandingkan mahasiswa lebih luas. Penelitian ini juga terbatas pada faktor pelatihan kewirausahaan, diharapkan penelitian selanjutnya dapat menambah faktor-faktor lain sehingga dapat diketahui faktor yang lebih efektif untuk menumbuhkan jiwa kewirausahaan.

\section{DAFTAR PUSTAKA}

Alma, B. (2016). Kewirausahaan dari Sudut Pandang Prikologi Kepribadian. Bandung: Alfabeta.

Arikunto, S. (2014). Prosedur Penelitian: Suatu Pendekatan Praktik. Jakarta: PT Rineke Cipta.

Christanti, A. (2016). Pembentukan Sikap Dan Intensi Kewirausahaan Di Sentra Industri Produk Roti Dan Kue Rungkut Lor, Surabaya. Agora, 4(1), 242-248.

Hamdani, M. (2012). Buku Ajar Entrepreneurship untuk Mahasiswa Sebuah Solusi untuk Siap Mandiri. Jakarta: CV. Trans Info Media.

Hermuningsih, S., \& Wardani, D. K. (2009). Faktor-Faktor yang Mempengaruhi Nilai Perusahaan yang Terdaftar di Bursa Efek Malaysia dan Bursa Efek Jakarta. Jurnal Siasat Bisnis, 13(2), 173-183.

Kasmir. (2016). Kewirausahaan. Jakarta: Rajawali Press.

Resmi, G. G. (2013). Membangun Jiwa Kewirausahaan Melalui Kegiatan Pelatihan Kewirausahaan Di Kalangan Mahasiswa ( Sebuah Model Pelatihan Kewirausahaan Di Kalangan Mahasiswa ). In Proceeding Seminar Nasional dan Call For Paper (SCA-3) (p. Vol.3, No.1.).

Simamora, H. (1995). Manajemen Sumber Daya Manusia. Yogyakarta: STIE YKPN.

Suratna. (2010). Pengembangan Jiwa Kewirausahaan Mahasiswa melalui Inkubator Bisnis, 6(2), 1-10.

Suryana. (2011). Kewirausahaan, Pedoman Praktis: Kiat dan Proses Menuju Sukses. Jakarta: Salemba Empat.

Wedayanti, N. P. A. A., \& Giantari, I. G. A. K. (2016). Peran Pendidikan Kewirausahaan Dalam Memediasi Pengaruh Norma Subjektif Terhadap Niat Berwirausaha. EJurnal Manajemen UNUD, 5(1), 533-560. 